\title{
The impact of migration on trade
} Immigrants are good for trade

Keywords: migration, international trade, trade facilitation

\section{ELEVATOR PITCH}

International trade and migration are two important dimensions of globalization. Although governments have been very willing to open their borders to trade, they have not been so liberal in their immigration policies. It has been suggested, however, that a causal positive link might exist between immigration and trade. Could governments further increase international trade by also opening their doors to immigrants? If they could, does it matter what type of immigrants are encouraged? And is there a saturation level of immigrants after which this positive impact disappears?

\section{KEY FINDINGS}

\section{Pros}

( There is a causal positive relationship between migration and international trade.

(- A $10 \%$ increase in the stock of immigrants can boost trade by an estimated $1.5 \%$ on average.

$\oplus$ Almost no studies have found a negative impact.

$\oplus$ Rich data with better and more immigration data than past studies yield similar results.
$10 \%$ increase in immigration boosts bilateral trade

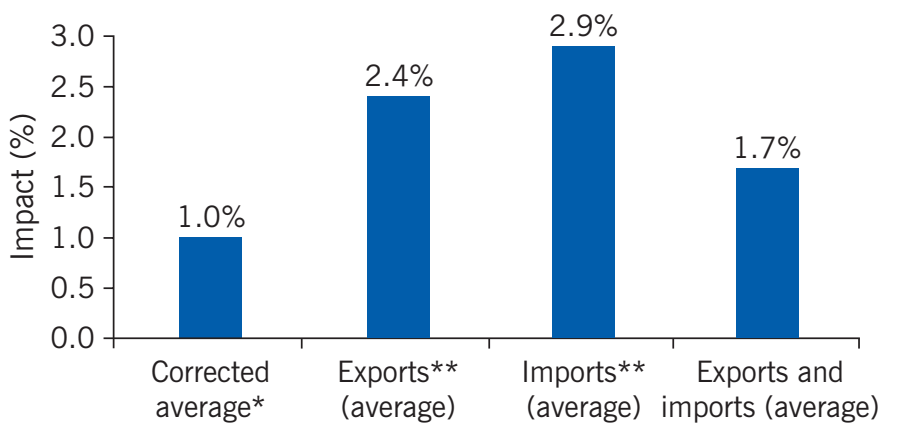

Notes: *Correct for overestimates in cross-sectional studies;

$* *$ Pre-2000 data.

Source: From 48 studies between 1994 and 2010 in [1].

\section{Cons}

- Some of the variation in the estimated effect of increased immigration on trade is due to the econometric methods used.

- Most studies do not allow the estimated effect of immigration on trade to differ for different immigrant stocks.

- Results from cross-sectional studies need to be interpreted with caution as they may overestimate the impact of immigrants.

\section{AUTHOR'S MAIN MESSAGE}

Immigration increases trade. The size of the impact depends on the type of sending countries, the type of commodities, the type of immigrants, and the size of the existing migrant population. So, it makes sense for governments to follow more liberal migration policies. Promoting the pro-trade impact of immigrants in a wider public domain could make citizens more tolerant of more liberal immigration policies. 


\section{MOTIVATION}

Although the growth in trade since the 1980s has been welcomed by the people and governments of many countries, the same cannot be said for immigration. Most governments design and implement policies to open their borders to trade but are not so willing to do the same with immigration. This is despite the many empirical studies in the literature that find a positive impact of migration on trade. There are estimates that a $10 \%$ increase in the global stock of immigrants might cause global trade to increase by $\$ 29$ billion and, for example, that each immigrant in Canada generated $\$ 8,000$ in Canadian imports and $\$ 3,000$ in exports in 1980-1992.

\section{DISCUSSION OF PROS AND CONS}

\section{Why might immigrants foster trade?}

A seminal paper in 1994 argued that the links immigrants have to their home country could foster bilateral trade flows between the home and host countries [2]. It is now widely accepted that migration can stimulate bilateral trade through two main mechanisms: transaction cost effects and immigrant preference effects.

Immigrants can lower the transaction costs for trade because of their superior knowledge of home country markets, language, customs, business practices, and laws. This direct trade-stimulating impact is likely to be greatest when the host and home countries have very different cultures, languages, and institutions, and when alternative sources of information are lacking-that is, when the informal trade barriers caused by these factors are greatest. Transaction cost effects are expected to affect both exports and imports. Immigrant preference effects, by contrast, are expected to boost only imports to the host country because they arise through the consumption channel as a result of immigrants' demand for the products from their home countries. It is also possible that demand for such goods increases among the host population as well, through a demonstration effect influencing the preferences of native-born residents. Over time, however, a countervailing immigrant substitution effect might also occur if the number of immigrants is high enough for domestic firms to start producing those products.

These channels can be termed direct immigrant links since they pertain to the effects of migrants whose country of birth relates to either the importing or the exporting country [3]. A related but indirect link may also exist. Ethnic minorities living outside their home countries create formal or informal networks to which both the host country and home country have access. These co-ethnic networks may promote trade by providing market information and supporting contractual enforcement. This network effect is another mechanism to overcome informal international trade barriers [4].

A voluminous literature has examined the link between immigrants and trade. A large majority of these studies focus on a single country and examine the link from the perspective of the home country, using data at either country or province (state) level. Others use bilateral data between pairs of many countries. Almost all of the studies find a positive immigrant impact on trade despite using different data, specifications, and estimation methods. This impact is typically estimated as an elasticity, which gives the percentage change in exports or imports associated with a $1 \%$ increase in the stock of immigrants (see Immigrant elasticity of trade). The estimated magnitude of the elasticity of trade with respect to immigration differs greatly across the studies. 


\section{Immigrant elasticity of trade}

The percentage change in trade associated with a $1 \%$ increase in the stock of immigrants.

\section{Estimates in studies between 1994 and 2010}

A quantitative review of 48 studies between 1994 and 2010 extracts 284 elasticities for exports and 229 elasticities for imports [1]. The vast majority of export and import elasticity estimates are positive. Only 13 elasticities are negative for exports and 19 for imports, but only two for imports-both -0.1-are statistically significant at the $10 \%$ level. The maximum estimated immigrant elasticity is 0.65 for Denmark's exports between 1995 and 2007 and for Australia's exports of organized exchange products between 1989 and 2000. The maximum estimated immigrant elasticity, 0.88 , is for imports of Organisation for Economic Co-operation and Development (OECD) countries between 1991 and 2000. The overall means of the estimated immigration elasticities of exports and imports are found to be the same, 0.17 , implying that a $10 \%$ increase in immigrants causes trade to increase by $1.7 \%$.

\section{Statistically significant results}

When the statistical significance of the estimated elasticities is taken into account, the overall means of elasticities of exports and imports are still equal or nearly equal. If it is assumed that there is one "true" elasticity that underlies all the studies, then the overall means of the elasticities of exports and imports are lower, with a value of 0.10 [1]. If it is assumed that the true impact varies from study to study in a random way, the overall mean of the immigration elasticity of exports is found to be 0.17 , with that of imports very close to it, 0.16 . Thus, the analysis of the 48 studies considered in the meta-analysis indicates that a $10 \%$ increase in the number of immigrants causes, on average, about a $1.5 \%$ increase in the volume of trade.

\section{Reasons for variation}

There are several reasons for the variation in elasticity estimates. The elasticities are estimated for different countries using different estimation methods and specifications and data for different periods. When a study uses pre-2000 data, elasticities are, on average, 0.07 higher for exports and 0.12 higher for imports. This suggests that the trade-inducing effect of immigrants is particularly strong when the first migrants from a particular origin arrive and that the impact becomes smaller once a sizable migrant community has been established [1]. Even after controlling for other factors, there are differences between countries in the immigrant elasticities of imports and exports. But it is not possible to identify the causes of such differences by study characteristics. Differences in immigration and trade policies of host countries may cause this variation. The trade facilitation effect of immigrants is lower for homogeneous goods, for which the immigrant preference effect is expected to be less. But there is no convincing evidence that the impact of immigrants on trade is greater for trade with developing countries than for trade with countries generally [1].

Panel-data models that include the lagged volume of trade in their specification yield smaller elasticities, particularly for imports (see Cross-section analysis, panel data analysis, and lagged variables). There is some evidence that inclusion of the income per capita variable in the model increases the estimated impact of immigration on imports. A distance variable 
is found to do the same for exports. The use of variables that account for geography (such as whether countries are landlocked or remote) removes some of the effect of migration on trade. But including culture or language does not make a difference in the estimated effects. A trade agreements variable reduces the immigrant elasticity of imports but not that of exports significantly. The effects of accounting for migrant skills or colonial ties are negligible. Accounting for migrants' duration of residence or home country generally makes no difference.

\section{Cross-section analysis, panel data analysis, and lagged variables}

Cross-section analysis refers to the analysis where many units of observation are observed at the same point in time or without regard to differences in time. Panel data analysis refers to the analysis when the same units of observation are observed across time. Cross-sectional analysis compares the differences among subjects while panel analysis examines changes in variables over time and differences in variables between subjects.

A lagged variable is a variable whose value is equal to its value from an earlier time period.

A common feature of the studies is that they all implicitly assume that immigration affects trade, not the other way around. When causality can run in both directions, regressions with cross-sectional data usually exaggerate the causal relationship. This is indeed the case for the estimated elasticities of imports but not for exports.

\section{Similar results in studies since 2010}

Quite a few studies published since 2000 employ the same methodology as in the studies discussed above. The range of estimated immigrant elasticities is consistent with the range in previous studies (see Figure 1). The greatest immigrant elasticity of exports, 0.48 , is obtained for US exports in 1991-2000. But the rest of the elasticities of exports are much smaller, with about half much lower than the overall mean of 0.15 . The greatest immigrant elasticity of imports, 0.30, is for Switzerland in 1995-2000. Some numbers are larger (row 5 ) but they represent the elasticity of imports with respect to the share of immigrants in the population [5].

\section{Bilateral ties}

Although the elasticities are almost always positive, their value is drastically reduced in panel-data analyses, which can account for unobserved heterogeneity in the data. For example, the impact of immigration is reduced by $88 \%, 70 \%$, and $42 \%$ for Italy, Portugal, and Spain respectively, when accounting for unobserved characteristics between countries and provinces that do not change over time and unobserved country-specific factors that change over time (row 1) [6]. The change is even more drastic-with the immigrant elasticity of trade becoming negative-when unobservable historical, cultural, and political ties are accounted for [3]. This suggests that there may be large biases in cross-sectional studies, simply because it is not possible to account for such unobservable factors when the trading partners are observed only once in a certain time period. 
Figure 1. Immigrant elasticity estimates in recent studies

\begin{tabular}{|c|c|c|c|}
\hline \multirow{2}{*}{$\begin{array}{l}\text { Country and } \\
\text { study period }\end{array}$} & \multirow{2}{*}{$\begin{array}{l}\text { Number of } \\
\text { sending/trading } \\
\text { countries }\end{array}$} & \multicolumn{2}{|c|}{ Immigrant elasticity } \\
\hline & & Exports & Imports \\
\hline $\begin{array}{l}\text { Provinces in } \\
\text { Italy, Spain, } \\
\text { Portugal } \\
2002-2010\end{array}$ & $\sim 100$ & $\begin{array}{l}0.17,0.02 \text { (Italy) } \\
0.27,0.08 \text { (Portugal) } \\
0.12,0.07 \text { (Spain) }\end{array}$ & \\
\hline $\begin{array}{l}\text { OECD } \\
\text { countries }\end{array}$ & 212 & $0.11,0.14$ & ns, 0.12 \\
\hline $\begin{array}{l}\text { US states } \\
1990,2000\end{array}$ & 29 & 0.14 & \\
\hline $\begin{array}{l}\text { OECD 1988-1990, } \\
\text { 1998-2000 }\end{array}$ & Many & $\begin{array}{l}0.12,0.06^{\mathrm{a}} \\
-0.14^{\mathrm{c}}, 0.23^{\mathrm{c}} \\
0.11,0.08^{\mathrm{a}} \\
\mathrm{ns}^{\mathrm{b}}, 0.13^{\mathrm{b}}\end{array}$ & $\begin{array}{l}\text { Total trade } \\
\text { elasticities }\end{array}$ \\
\hline OECD 2000 & OECD & & $\begin{array}{l}0.28^{d}, 0.69^{c d} \\
0.32^{d} 0.80^{c d} \\
0.19^{d}, 0.46^{c d} \\
0.31,0.76^{c d}\end{array}$ \\
\hline Turkey 1980-2007 & 13 EU countries & $0.10^{\mathrm{e}}$ & $0.05^{\mathrm{e}}$ \\
\hline OECD 2008 & 23 & 0.04 & $\begin{array}{l}\text { Total trade } \\
\text { elasticity }\end{array}$ \\
\hline US 1991-2000 & 63 & 0.48 & 0.27 \\
\hline World 1960-2000 & 178 & $\begin{array}{l}0.05,0.04,0.05 \\
0.07,0.05 \\
0.06,0.06 \\
-0.02\end{array}$ & $\begin{array}{l}\text { Cross-section } \\
\text { For 2000, } \\
\text { 1990, 1980, } \\
\text { 1970, 1960 } \\
\text { Pooled } \\
\text { regression }\end{array}$ \\
\hline $\begin{array}{l}43 \text { African } \\
\text { home } \\
\text { countries plus } \\
67 \text { other } 2005\end{array}$ & $43 / 110$ & 0.13 & 0.26 \\
\hline 110,2005 & 131 & 0.15 & 0.17 \\
\hline $\begin{array}{l}\text { Switzerland } \\
\text { 1995-2000 }\end{array}$ & Many & $0.10,0.27$ & $0.13,0.30$ \\
\hline
\end{tabular}

Notes: Immigrant elasticity is the percentage change in trade (exports or imports or total trade) associated with a $1 \%$ increase in the number of immigrants; ns means not statistically significant. a Low-skilled migrants. ${ }^{\text {bMedium-skilled }}$ migrants. ${ }^{\mathrm{C}} \mathrm{High}$-skilled migrants. ${ }^{\mathrm{d}}$ With respect to the share of immigrants. ${ }^{\mathrm{e}}$ Emigrant elasticity.

Source: Data compiled from [3], [5], [6], [7], and materials listed in the additional references at: http://wol.iza.org/articles/impact-of-migration-on-trade.

\section{Impacts in dollars}

The overall average elasticity of 0.15 may seem quite low. But its economic significance is quite important. Consider the estimated elasticity of 0.11 for OECD countries, using the mean values of migrant population and total trade in 2000. It implies that one additional migrant creates about $\$ 2,700$ in additional trade [7]. Or with the immigrant elasticity of 0.05 for global trade in 2000, a $10 \%$ increase in the global stock of immigrants is associated with a $\$ 29$ billion increase in world trade. An additional immigrant from Singapore has the largest potential to boost trade: an additional $\$ 29,359$ in exports and $\$ 47,708$ in imports. The lowest impact is by immigrants from the Philippines, with $\$ 6$ generated in imports and 
$\$ 4$ in exports [2]. Each immigrant to Canada generates $\$ 8,000$ in Canadian imports and $\$ 3,000$ in Canadian exports, using data for 1980-1992 [8].

\section{Including emigrants}

Although the vast majority of studies have considered only the impact of immigrants, some recent studies also assess the effect of emigration by making use of richer migration data sets. Both immigrant and emigrant stocks should be included in the estimation of gravity models and failing to capture both is likely to bias results upwards [3]. Both immigrant and emigrant elasticities of trade are significant and stable across the decades, ranging from 0.04 to 0.05 , with the immigrant elasticity never statistically larger than the emigrant elasticity [3]. (Though the positive effect disappears when bilateral ties are accounted for, as mentioned above.)

A study using cross-sectional 2005 data for 131 home countries and 110 host countries examines how the size of a home country's emigrant flows to multiple host countries affects the volume of trade between the home and host countries. The analysis reveals positive influences of emigrants on their home country's trade in 100 of the 131 home countries for imports and 96 for exports. The estimated effects vary significantly across the home countries. For example, the strongest pro-export effects are for emigrants from Equatorial Guinea (0.84) and Papua New Guinea (0.64). The weakest effects are from South Africa (0.01) and China (0.014). Emigrants from developing countries generally have stronger effects on their home country's trade with their respective host country than do emigrants from developed countries. The elasticity of Turkey's trade with respect to the stock of Turkish emigrants in host trading partners in Europe is 0.08 for total trade, 0.10 for exports, and 0.05 for imports in a study that uses data for 1980-2007.

\section{Distinguishing skill levels}

A richer migration data set also allows us to distinguish between the skill levels of immigrants [7]. The elasticity of trade with respect to the total stock of immigrants to OECD countries is 0.11 , with 0.08 for low-skilled immigrants and 0.13 for high-skilled immigrants. The mediumlevel skilled immigrants have no statistically significant impact.

\section{Distinguishing occupation}

Although it is typical to equate the total immigrant population with the size of the business network that enhances bilateral trade, there are reasons to believe that the total immigrant population is a poor and noisy measure of the business networks that immigrants establish. Individuals employed directly in business network occupations are found to produce more than double the value of trade compared with average migrants when immigrants who actually participate in a trade-business network are identified in data that cover 89 destination countries and 233 countries of origin [9]. A 10\% increase in the average stock of immigrants implies that one additional immigrant generates an extra $\$ 25,516$ of imports, which increases by an additional $\$ 35,124$ if all additional immigrants were to be employed in business network occupations. Business migrants-in managerial and sales jobs-with the highest education have the most unambiguous pro-trade effect. 


\section{Importance of the weakness of institutions and cultural difference}

Findings in recent studies suggest that the business network effect of immigrants is especially important for culturally distant countries, such as countries with different legal origins or languages. A recent study of Germany's trade found that the most efficient migrant networks originate from African or Middle-Eastern countries rather than from EU countries. This is consistent with the view that the presence of migrant business networks is less relevant when countries already have commonalities. But migrant business networks become more relevant in countries with weak institutions as they serve as a substitute. This is a possible explanation for a larger pro-export effect for African exports.

\section{Distinguishing intensive and extensive margins}

Data on US state exports in 1990 and 2000 show that the ethnic-network elasticity of trade in an existing trading relationship (in the intensive margin) was 0.14 but that the impact on the probability of entering an export market was not statistically different from zero. This implies that although ethnic networks are associated with increased exports when a trading relationship already exists, there is no association between ethnic networks and entry into an export market. The term extensive margin refers to the probability of new trading relationships. It also refers to the number of transactions or the number of products traded. In this instance, the immigrant effect is almost entirely due to an increase in the extensive margin, with little or no impact on expansion of existing trade flows. A very recent study using firm-level data also finds that immigrants exert a stronger effect on the extensive margin than on the intensive margin.

\section{Variety of imports}

From 1988 to 2007 Canada's import varieties grew 76\%, associated with a welfare gain to Canadian consumers as large as $28 \%$. Enhanced immigration flows are responsible for $25 \%$ of this growth in variety. So the average Canadian consumer was about $7 \%$ better off in 2007 than in 1998 simply due to the enhanced variety of imported goods associated with immigration.

\section{Firm-level data}

Detailed 2005 firm-level data for Portugal show that larger stocks of emigrants increase the likelihood of exports. If a firm serves a market, the presence of emigration stocks is an important driver of how much it sells there. Matched employer-employee firm-level data from Denmark for 1995-2005 show a robust positive impact of the employment of foreigners on export sales-of at least 1.2\% higher export sales per additional employee.

\section{Threshold effects}

The trade-enhancing effect of immigrants may work only for a certain number of immigrants. It is also possible that the impact of immigrants may reach its maximum at some level of immigrants once it kicks in. It may even be that the stimulating effects of immigrants on trade are subject to decreasing returns as the number of immigrants increases and can even become ineffective or negative beyond a certain level. 
Cross-sectional data on migrants in 27 OECD countries from 130 economies for 2000 show that the impact of immigrants is positive only for immigration stocks between about 100 and 4,000 persons. If the number exceeds 4,000, immigrants do not trigger any additional imports. Cross-sectional provincial data for Spain and Italy show that the response of province exports to immigrants from a given nationality is always positive. But its magnitude varies with the number of immigrants: rising from 1 to 100 immigrants, falling between 101 and 1,500, and rising again with more than 1,500. For both countries, the largest value of the potential exports is reached when the number of immigrants of the same nationality living in the same province reaches 70 for Italy and 100 for Spain.

\section{Using evidence to shape public opinion}

It has long been accepted that migration is beneficial from an economic point of view, and more liberal migration policies have been recommended many times. But this has never made that much impact on government policies. The European Blue Card is a good example of how governments behave when it comes to opening their borders to immigrants.

\section{The European Blue Card}

An approved EU-wide work permit that allows high-skilled non-EU citizens to work and live in any country within the EU, excluding Denmark, Ireland, and the UK.

A purely economic framework is obviously not well-suited to explain the policies implemented by most countries. Policymakers seem to take public opinion into account when they formulate migration policy, and only a small minority of voters favor more open migration policies in most countries [10].

Perhaps the evidence on the positive impact of immigrants can be most useful in shaping public opinion. Opinions on trade and immigration are positively correlated, with individuals being more pro-trade than pro-immigration. If an individual is 3.3 times more likely to favor a more open trade regime than a more open migration regime, it may be possible to lower the resistance to more open immigration policies by promoting the positive link between immigration and trade [11]. This should make it easier for policymakers to adopt more liberal immigration policies.

\section{LIMITATIONS AND GAPS}

Although all the empirical evidence points to a pro-trade immigrant effect, there are issues with the econometric methods. The crucial issue is the direction of causality between trade and migration. But that has been specifically addressed particularly in recent studies, usually with an instrumental variables approach, which finds a causal impact of immigration on trade.

Another critical issue is that almost all of the studies implicitly assume that the immigrant elasticity of trade does not depend on the level of immigrant stock. Although this can be resolved by specifying the functional forms in the model accordingly, most studies have not done so. Recent studies show that the magnitude of the immigrant elasticity does in fact vary with the level of immigrant stock. Similarly, attention has been paid only recently 


\section{Instrumental variables estimation}

Instrumental variables is a method of estimation that is used when it is not possible to estimate correctly the causal impact of a variable due to invalidity of the statistical assumptions required. The method simply semi-replaces the defective variable with another variable that is called an instrument (or instrumental variable). The instrument needs to be partially correlated with the defective variable and uncorrelated with the error term in the equation, and should not belong to the equation itself.

to the possibility that the impact of immigrants may be different for immigrants with different skills.

Studies that use panel data (where the same trading partners are observed across time) show how important it is to control for unobserved bilateral ties in addition to controlling for other unobserved country-specific factors. Studies that fail to control for such unobserved heterogeneity are likely to overestimate the impact of immigrants. Because cross-sectional studies cannot by their nature account for such factors, their results should be interpreted with more caution.

\section{SUMMARY AND POLICY ADVICE}

There is ample empirical evidence for a pro-trade impact of migration. Although the immigrant elasticity estimates differ greatly across studies, their average is about 0.15 , implying that trade increases on average by $1.5 \%$ when the number of immigrants increases by $10 \%$. But a substantial proportion of the elasticity estimates is based on cross-sectional studies. Given that cross-sectional studies may have overestimated the impact of immigration, the true average is more likely to be about 0.10 . There is also evidence that the impact of immigrants on trade varies with the type of immigrants, with high-skilled or better-educated immigrants having a larger pro-trade impact, especially if they are employed directly in business network operations. Recent studies also show that not just the host country benefits, but the sending countries benefit as well.

A win-win situation like this suggests that liberalizing migration policy can further reduce trade barriers to facilitate trade. Thus, it would make sense for governments to follow more liberal migration policies. These policies can be formulated in a way that encourages particularly high-skilled immigrants, as their pro-trade impact is larger.

\section{Acknowledgments}

The author thanks an anonymous referee and the IZA World of Labor editors for many helpful suggestions on earlier drafts.

\section{Competing interests}

The IZA World of Labor project is committed to the IZA Guiding Principles of Research Integrity. The author declares to have observed these principles.

(c) Murat Genç 


\section{REFERENCES}

\section{Further reading}

Genç, M., M. Gheasi, J., Poot, and P. Nijkamp. "The impact of immigration on international trade: A meta-analysis." In: Nijkamp, P., J. Poot, and M. Sahin (eds). Migration Impact Assessment: New Horizons. Cheltenham, UK: Edward Elgar, 2013; pp. 301-337.

Gould, D. M. "Immigrant links to the home country: Empirical implications for United States bilateral trade flows." Review of Economics and Statistics 76:2 (1994): 302-316.

Rauch, J. E. "Business and social networks in international trade." Journal of Economic Literature 39:4 (2001): 1177-1203.

\section{Key references}

[1] Genc, M., M. Gheasi, J. Poot, and P. Nijkamp. "The impact of immigration on international trade: A meta-analysis.” In: Nijkamp, P., J. Poot, and M. Sahin (eds). Migration Impact Assessment: New Horizons. Cheltenham, UK: Edward Elgar, 2013, pp. 301-337.

[2] Gould, D. M. "Immigrant links to the home country: Empirical implications for United States bilateral trade flows." Review of Economics and Statistics 76:2 (1994): 302-316.

[3] Parsons, C. R. Do Migrants Really Foster Trade?: The Trade-Migration Nexus, a Panel Approach 19602000. World Bank Policy Research Working Paper No. 6034, 2012.

[4] Rauch, J. E. "Business and social networks in international trade." Journal of Economic Literature 39:4 (2001): 1177-1203.

[5] Felbermayr, G. J., and F. Toubal. "Revisiting the trade-migration nexus: Evidence from new OECD data." World Development 40:5 (2011): 928-937.

[6] Artal-Tur, A., V. J. Pallardó-López, and F. Requena-Silvente. "The trade-enhancing effect of immigration networks: New evidence on the role of geographic proximity." Economics Letters 116:3 (2012): 554-557.

[7] Felbermayr, G. J., and B. Jung. "The pro-trade effect of the brain drain: Sorting out confounding factors." Economics Letters 104:2 (2009): 72-75.

[8] Head, K., and J. Ries. "Immigration and trade creation: Econometric evidence from Canada." Canadian Journal of Economics 31:1 (1998): 47-62.

[9] Aleksynska, M., and G. Peri. "Isolating the network effect of immigrants on trade." World Economy 37:3 (2013): 434-455.

[10] Facchini, G., and A. M. Mayda. "From individual attitudes towards migrants to migration policy outcomes: Theory and evidence.” Economic Policy 23:56 (2008): 651-713.

[11] Mayda, A. M. "Why are people more pro-trade than pro-migration?" Economics Letters 101:3 (2008): 160-163.

The full reference list for this article is available from the IZA World of Labor website (http://wol.iza.org/articles/impact-of-migration-on-trade). 